\title{
Correction to: Examining acculturation orientations and perceived cultural distance among immigrant adolescents in Portugal: links to performance in reading, mathematics, and science
}

\author{
Michael Melkonian ${ }^{1}$. Shaljan Areepattamannil ${ }^{1}$. Luisa Menano ${ }^{1}$. \\ Patricia Fidalgo ${ }^{1}$
}

Published online: 5 March 2020

(c) The Author(s) 2020

\section{Correction to: Social Psychology of Education (2019) 22:969-989 https://doi.org/10.1007/s11218-019-09506-5}

In the following paper "Examining acculturation orientations and perceived cultural distance among immigrant adolescents in Portugal: links to performance in reading, mathematics, and science" by Michael Melkonian, Shaljan Areepattamannil, Luisa Menano and Patricia Fildago, one of the authors' names was inadvertently misspelled. The article was originally published without open access.

The correct spelling of the last author should be "Patricia Fidalgo".

The article "Examining acculturation orientations and perceived cultural distance among immigrant adolescents in Portugal: links to performance in reading, mathematics, and science", written by Michael Melkonian, Shaljan Areepattamannil, Luisa Menano, Patricia Fidalgo, was originally published Online First without Open Access. After publication in volume 22, issue 4, page 969-989 the author decided to opt for Open Choice and to make the article an Open Access publication.

With the author(s)' decision to opt for Open Choice, the copyright of the article changed on (2019) to (C) The Author(s) 2020 and the article is forthwith distributed under the terms of the Creative Commons Attribution 4.0 International License (http://creativecommons.org/licenses/by/4.0/), which permits use, duplication, adaptation, distribution and reproduction in any medium or format, as long as you give appropriate credit to the original author(s) and the source, provide a link to the Creative Commonslicence, and indicate if changes were made. The images or other third party material in this articleare included in the article's Creative Commons licence,

The original article can be found online at https://doi.org/10.1007/s11218-019-09506-5.

Michael Melkonian

mmelkonian@ecae.ac.ae

1 Emirates College for Advanced Education, Abu Dhabi, United Arab Emirates 
unless indicated otherwise in a credit line to thematerial. If material is not included in the article's Creative Commons licence and your intended use isnot permitted by statutory regulation or exceeds the permitted use, you will need to obtain permissiondirectly from the copyright holder. To view a copy of this licence, visit http:// creativecommons.org/licenses/by/4.0/.

Springer wishes to apologize for any inconvenience caused.

Open Access This article is licensed under a Creative Commons Attribution 4.0 International License, which permits use, sharing, adaptation, distribution and reproduction in any medium or format, as long as you give appropriate credit to the original author(s) and the source, provide a link to the Creative Commons licence, and indicate if changes were made. The images or other third party material in this article are included in the article's Creative Commons licence, unless indicated otherwise in a credit line to the material. If material is not included in the article's Creative Commons licence and your intended use is not permitted by statutory regulation or exceeds the permitted use, you will need to obtain permission directly from the copyright holder. To view a copy of this licence, visit http://creativecommons.org/licen ses/by/4.0/.

Publisher's Note Springer Nature remains neutral with regard to jurisdictional claims in published maps and institutional affiliations. 